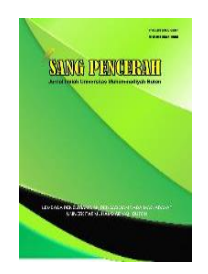

Volume 6 Issue 1, 2020

P-ISSN : 2528-360X, E-ISSN : 2621-6159

Website: https://www.jurnal-umbuton.ac.id/index.php/Pencerah

\title{
Pengaruh Harga Terhadap Keputusan Pembelian Maksker Garnier
}

\section{Firman Gazali Djunaidi}

Email: firmanuniqbu@gmail.com

\begin{abstract}
A large number of mask products cause consumer choices in determining. The research aims to examine the effect of prices on Garnier mask purchasing decisions in the Buru District. This research uses survey research type In this study is one independent variable and one dependent variable. The independent variable in this study is the price, and the dependent variable is the purchasing decision. The type of data used in this study is interval data, which are measurement results that can be ordered based on specific criteria. The population in this study is a combination of all the elements that form events; thus, what is meant by the user of the Garnier mask in Buru Regency. A validation test is used to measure the validity of the questionnaire. A question raised will be asked by the researcher requesting the problem to be asked by the researcher. The results showed a significant influence on the price determination of Garnier purchasing decisions in the Buru Regency. This is following the test variables, namely variable variation of 0.307, so decisive for purchases if the product varies and test the price variable for adjustment of shopping in the variable variables found positive influence on purchasing decisions that are 0.176.

Keywords: Garnier; Buyer; Interest
\end{abstract}

\begin{abstract}
Abstrak
Banyaknya produk penjualan masker meneyebabkan adanya pilihan konsumen dalam menentukan pemeblian. Penelitian betujuan untuk menelaah pengaruh harga terhadap keputusan pembelian masker garnier di Kabuapte Buru. Penelitian ini merupaka jenis penelitian Survai Dalam penelitian ini terdapat sau variable independen dan 1 variable dependen. Variable independen dalam penelitian ini adalah pengaruh harga dan variable dependen adalah keputusan pembelian. Jenis data yang digunakan pada penelitian ini adalah data interval yakni hasil pengukuran yang dapat diurutkan atas dasar kriteria tertentu. Populasi dalam penelitian ini yakni gabungan dari seluruh elemen yang berbentuk peristiwah dengan demikian bahwa populasi yang dimaksud adalah konsumen pengguna masker Garnier di Kabupaten Buru. Uji validasi digunakan untuk mengukur valid tidaknya kuisioner. Suatu kuisioner akan dikatakan valid apabila pertanyaan yang terdapat dalam kuisioner mampu suatu yang akan diutur oleh kuisioner atau penyesuaian jawaban terhadap pertanyaan yang diajukan oleh peneliti. hasil penelitian menunjukkan bahwa adanya pengaruh yang signifikan terhadap penentuan harga terhadap keputusan pembelian garnier di Kabupaten Buru. Hal ini sesuai dengan pengujian variabel diantaranya yakni variabel variasi yakni sebesar 0,307 jadi ada pengaruh positif terhadap pembelian jika produk tersebut bervariasi dan pengujian variabel harga terhadap pengaruh pembelian dalam pengukuran variabel harga ditemukan adanya pengaruh positif terhadap keputusan pemmbelian yaitu 0,176.

Kata Kuci: Garnier; Pembeli; Minat
\end{abstract}

\section{PENDAHULUAN}

Perusahaan Garnier tak kehabisan akal dalam mengembangkan produk produk baru mereka demi dapat bersaing di pasaran dan untuk memuasakan para konsumen setia Garnier. Setelah Garnier sukses akan produk pewarna rambut hingga produk kecantikan lainnya kini Garnier kembali meluncurkan produk yang tak kalah bagusnya dengan produk

\footnotetext{
${ }^{1}$ Universitas Iqra Buru, Indonesia
} 
sebelumnya, yaitu Masker instan yang dapat memudahkan konsumen dalam mengaplikasikannya. Hal ini diungkapkan juga oleh Groover (2010) bahwa variasi suatu produk dapat diartikan sebagai prodak yang mempunyai desain atau variasi yang berbeda antara satu dan lainya.

Tak hanya monoton dalam satu varian masker saja Garnier jeli dalam melihat kebutuhan konsumen mereka yang memiliki masalah kulit yang berbeda, maka Garnier meluncurkan beberapa varian untuk menjawab kebutuhan para konsumen. Sehingga diproduksinya garnier sesuai dengan kebutuhan serta jenis kulit konsumen.

Produksi pertama dari garnier adalah Masker Light Complete Whithening Peel of Mask pada produk ini bermanfaat untuk mengangkat kotoran dan sesl-sel kulit mati serta dapat mencerahkan kulit wajah.

Masker peel off dari garnier ini mengandung ekstrak lemon yang segar, selain dapat mengangkat sel kulit mati masker ini juga mampu mencerahkan kulit, menyerap minyak berlebih pada wajah tanpa membuat kulit jadi kering, membersihkan kotoran bekas jerawat, dan membersihkan komedo.

Dan telah hadir produk baru dari garnier yaitu masker wajah Sakura White yang diperkaya ekstrak bunga sakura yang lembut, bunga yang berasal dari jepang Essence dengan paduan ekstrak sakura, Vitamin B3 dan Vitamin CG yang bermanfaat untuk melembabkan kulit wajah hingga ke lapisan kulit bagian dalam, mencerahkan kulit wajah yang kusam, menghilangkan bintik hitam, komedo dan noda bekas jerawat, serta membantu merawat elastisitas kulit wajah agar tetap lembut. Masker ini juga sangat cocok untuk setiap jenis kulit termasuk kulit yang sensitif.

Kemudian Garnier Pure Active matcha ini diperkaya denga $2 x$ matcha green tea yang rasa hangatnya ketika dikulit dapat membantu membuk poripori sekaligus membersihkan kotoran yang terjebak dalam pori-pori wajah. Masker pure active matcha ini sangat cocok untuk kulit berjerawat. Produk ini sangat aman untuk kulit kering asal sesai dengan aturan pengaplikasiannya.

Dalam varian produk tersebut juga dapat memepengaruhi keputusan pembeli/konsumen terhadap pemebelian produk. Namun dalam penjualan produk harusnya memeperhatikan harga jual karena factor penjualan sanagat memepengaruhi minat pembeli sebab konsumen tidak tidak sedikit memebandingkan produk satu dengan yang lainya teruatama masalah harga penjualan (firman: 2019)

Hal ini sesuai dengan pendapat (Tjiptono: 2010) bahwa harga memeiliki peran utama dalam proses pengambiloan keputusan para pembeli, yakni. a) peranan harga, yaitu fungsi harga dalam membantu pembeli untuk memeutuskan cara memeperoleh manfaat atau kuwalitas tertinggi yang diharapkan berdasar daya belinya b) peranan informasi harga, yakni funfsi harga dalam membidik konsumen mesalnya dalam kulaitas.

Untuk itu setiap konsumen sealau memiliki pertimbangan dalam membeli suatu produk tertentu misalnya memepertimbangkan harga, kualitas dan bentuik/ keindahan produk (pembungkus atau kemasan). Menurut Buchari Alma (2005) dalam keputusan pembeli ada beberapa hal yang memepengaruhi konsumen untuk tertarik dengan suatu barang diataranya factor pemasaran terhadap penjualan dari perusahaan atau si produksi barang.

Kotler dan Keller 2009. Pemasaran adalah usaha keompok atau individu untuk menciptakan dan menawarkan terhadap prodak secara luas dan terbuka untuk memepertukarkan produk dengan jasa yang bernillai kepada konsumen atau 
pembeli. Pemasaran juga merupakan usaha sadar suatu individu dalam memprotomosikan dan menentukkan harga barang dan jasa sehingga membuat konsumen tertarik dengan barang yang dipasarkan.

Melalui gambaran pengertian pemasaran di atas dapat disimpulkan bahawa pemasaran adalah usaha sadar untuk merencanakan, menentukkan harga, dan memepromosikan produk untuk menarik simpati pembeli untuk mendapatkan hasil yang maksimal sesuaqi targer si penawar jasah.

Dalam kegiatan pemasaran tentu ada factor-faktor yang harus dicapai sehingga barang tersebut dapat berterima dipasaran atau dapat menarik minat pembeli. Factor tersebut diantaranya:

a. Menentukan harga/memperkirakan harga

Perusahaan menetapkan biaya yang terendah dan membatasi harga tertinggi yang dapat ditentukkan perusahaan bagi produknya. Hal ini bertujuan untuk menutupi biaya dalam dalam mendistribusikan produknya.

b. Menganalisis harga dan penawaran pesaing

Hal ini bertujuan untuk melihat fenomena pemasaran produkproduk yang mirip untuk melihat harga terendah dalam pemsaran sehingga produk yang ditawarkan tidak melampaui harga pesaing sehingga produk dapat dipromoiskan pada pasar dan berterima dalam pemasaran.

c. Memilih Metode Dalam Menetapkan Harga

Menerapkan 3C Customer dema Schedule, cost Function, dan competition price. Atau prmintaan konsumen, fungsi biaya dan harga pesaing. Dalam penerapan ini perusahaan dapat mengahasilkan keuntungan untuk mengahsilkan permintaa.

\section{d. Menentukkan harga Akhir}

Dalam menetukan harga produsen atau penghasil jasah menerapkan berbagai metode untuk menentukkan harga akhir terhadap barang yang dipromosikan.

Harga merupakan ukuran terhadap besar kecilnya nilai keouasan konsumen terhadap barang dan jasah yang dibelinya. Konsumen akan berani memebli dan membayar suatu produk dengan harga tinggi apabila produk tersebut dapat diharapkan dan mencapai kepuasan kwalitas dan manfaat produk itu. Sebaliknya apanila konsumen meniai barang tersebut tidak ada kepusan maka produk tersebut walaupun memepunyai harga rendah maka konsumen atau pembeli tidak akan memebelinya. Jadi dapat disimpulkan bahwa harga berterima apabila ada kepuasan pembeli terhadap produk yang dibeli.

Dalam bertransaksi pembeli dan penjual akan memeperoleh imbalan apabila adanya sebuah kesapakatan terhadap barang yang ditawarkan hal inilah yang dapat digambarkan dalam pegambilan keputusan pembeli dalam memeilih produk.

Dari latar belakang di atas maka yang menajadi permasalahan dalam penelitian ini adalah bagaimanakah pengaruh harga terhadap keputusan pemebelian masker Garnier.

\section{METODE}

Penelitian ini merupaka jenis penelitian Survai. Menerut Effendi (1989) penelitian Survai adalah penelitian yang menagambil sampel dari suatu populasi dengan menggunakan kuisioner sebagai alat untuk mengumpulkan data dalam penelitian.

Dalam penelitian ini terdapat sau variable independen dan 1 variable dependen. Variable independen dalam 
penelitian ini adalah pengaruh harga dan variable dependen adalah keputusan pembelian.

Jenis data yang digunakan pada penelitian ini adalah data interval yakni hasil pengukuran yang dapat diurutkan atas dasar kriteria tertentu. Populasi dalam penelitian ini yakni gabungan dari seluruh elemen yang berbentuk peristiwah dengan demikian bahwa populasi yang dimaksud adalah konsumen pengguna masker Garnier di Kabupaten Buru. Dalam penentuan sampel peneiti tidak mungkin menagambil keselutuahan populasi untuk itu peneliti membentuk perwakilan populasi dalam menentukkan sampel hal ini sesuai dengan teori Ferdinand (2006). Sehingga peneliti dalam menentukan sampel mnggunakan rumus Rao Purba (Sujarweni: 2015) yakni:

$$
n=\frac{z^{2}}{4(m o e)^{2}}
$$

Keterangan:

$$
\mathrm{n}=\text { Jumlah sampel }
$$

$\mathrm{Z}=\mathrm{B} 1,96$ score pada tingkat signifikansi tertentu (95\%)

moe = tingkat kesalahan tertentu adalah $10 \%$

Data kuantitatif merupakan data yang disajikan berbentuk verba bukan dalam angka-angka data kualitatif digunakan dalam penelitian ini untuk mendapatkan gambaran objek penelitian (iye risman 2018) miasalnya sejarah singkat, visi, suatu produk. Kemudian data kuantitatif yakni data yang diukur dan dihitung secara langsung oleh peneliti (Sugiono: 2010).

Uji validasi digunakan untuk mengukur valid tidaknya kuisioner. Suatu kuisioner akan dikatakan valid apabila pertanyaan yang terdapat dalam kuisioner mampu suatu yang akan diutur oleh kuisioner atau penyesuaian jawaban terhadap pertanyaan yang diajukan oleh penliti.

\section{PEMBAHASAN}

\subsection{Karektristik Responden}

Dalam penentuan responden digunakan dalam penelitian ini adalah konsumen pengguna masker di Kbupaten Buru sebanyak 100 (seratus) orang. Dari penentuan smapel tersebut memeliki karakteristik yang berbeda-beda. Karakterikstik tersebut diantaranaya:

\section{a. Usia}

Tabel 1. Karakteristik jumlah responden berdasarkan usia

\begin{tabular}{ccc}
\hline Usia (Tahun) & $\begin{array}{c}\text { Responden } \\
\text { (Orang) }\end{array}$ & $\begin{array}{c}\text { Presen } \\
\text { tase } \\
\text { (\%) }\end{array}$ \\
\hline $17-25$ & 60 & $60 \%$ \\
\hline $26-35$ & 40 & $40 \%$ \\
\hline Jumlah & 100 & $100 \%$ \\
\hline
\end{tabular}

Dari table diatas tergambar bahwa sebagaian besar responden yang mennguanakn masker pada usia 17-25 tahun yaitu pada tingkat angka presentase sebesar $60 \%$, dan sisanya adalah responden pengguna masker yang berusia 26 - 35 tahun yaitu pada tingkat angka presentase sebesar $40 \%$.

\section{b. Deskriptif Variabel Penelitian}

Pada deskriptif variable penelitian yakni untuk menegungkapkan hasil distribusi jawaban responden dari data yang telah dikumpulkan. Pada desriptif ini terdapat lima kategori jawaban dari responden, Dalam memberikan penilaian dari hasil jawaban responden maka digunakan prisip dari pembobotan yakni rentang skala kategori nilai. Rentang kategori tersebut di deskripsikan melalui table dibawah ini: 
Table 2. Kategori rata-rata skor pernyataan

\begin{tabular}{ccc}
\hline No & $\begin{array}{c}\text { Makna } \\
\text { kategori }\end{array}$ & Nilai/skor \\
\hline $\mathbf{1}$ & $\begin{array}{c}\text { Sangat tidak } \\
\text { setuju }\end{array}$ & 1 \\
$\mathbf{2}$ & Tidak setuju & 2 \\
$\mathbf{3}$ & neutral & 3 \\
$\mathbf{4}$ & Setuju & 4 \\
$\mathbf{5}$ & Sagat setuju & 5 \\
\hline
\end{tabular}

\section{a. Deskripsi Variabel Responden Variasi Produk}

Pengukuran variabel variasi produk yang digunakan dalam penelitian ini tersebar dalam tiga jenis pernyataan yang dibentuk dalam 3 definisi yang diadopsi dari Kotler dan Keller (2008) meliputi: (1) Variasi ukuran volume/isi (2) Perbandingan harga dengan pesaing dan (3) Penampilan kemasan.

Tabel 3. Variabel Responden Variasi Produk

\begin{tabular}{|c|c|c|c|c|c|}
\hline \multirow{2}{*}{ No } & \multirow{2}{*}{ Indikator } & \multicolumn{4}{|c|}{ Skor } \\
\hline & & SS & $\mathbf{S}$ & N TS & STS \\
\hline 1 & $\begin{array}{l}\text { Isi yang terdapat dalam } \\
\text { produk Garneier lebih } \\
\text { banyak disbanding } \\
\text { dengan masker lain. }\end{array}$ & 38 & 50 & 111 & 0 \\
\hline 2 & $\begin{array}{l}\text { Masker Garnier memiliki } \\
\text { harga yang cukup } \\
\text { kompetitif dibandingkan } \\
\text { dengan pesaing. }\end{array}$ & 38 & 34 & 207 & 1 \\
\hline 3 & $\begin{array}{l}\text { Kemasan Masker Garnier } \\
\text { menarik dan mudah } \\
\text { dikenali. }\end{array}$ & 33 & 37 & $18\lfloor 2$ & 0 \\
\hline
\end{tabular}

Deskripsi Variabel Responden Variasi Produk Berdasarkan Tabel 3 diatas untuk indikator variasi ukuran, volume/isi:

a) 38 Reponden menyatakan sangat setuju

b) 50 reponden menyatakan setuju

c) 11 reponden netral

d) 1 responden manyatakan tidak setuju

Jadi dapat disimpulkan bahwa sebagaian besar responden setuju bahwa isi masker garnier lebih banyak dibanding dengan masker lain.
Untuk indicator perbandingan harga dengan pesaing respon responden yakni:

a) 38 reponden menyatakan sangat setuju

b) 34 responden menyatakan setuju

c) 20 responden menyatakan netral

d) 7 reponden menyatakan tidak setuju

e) 1 responden tidak setuju

Dari hasil indicator perbandingan harga maka dapat disimpulkan bahwa sebagian besar responden menyatakan sangat setuju bahwa harga masker garnier mempunyai harga yang cukup kompetitif dengan dibandingkan dengan pesaing lain.

Kemudian untuk indikator perbandingan harga dengan pesaing 33 responden menyatakan sangat setuju, 37 responden menyatakan setuju, 18 responden menyatakan netral, dan 12 responden menyatakan tidak setuju, jadi dapat disimpulkan sebagian besar responden menyatakan setuju bahwa kemasan Masker Garnier menarik dan mudah dikenali.

\section{b. Deskripsi Variabel Responden Harga}

Pengukuran variabel dalam penentuan harga penelitian ini tersebar dalam tiga bentuk pertnyaan yang dibentuk dalam tiga definisi yakni: harga uang sesuai dengan manfaat, harga terjangkau, dan kulitas dan harga sesuai.

Tabel 4. Tabel Tanggapan Responden Mengenai Harga

\begin{tabular}{lllllll}
\hline \multirow{2}{*}{ No } & \multicolumn{1}{c}{ INDIKATOR } & \multicolumn{5}{c}{ SKOR } \\
\cline { 2 - 6 } & SS & S & N & TS & STS \\
\hline 1 & $\begin{array}{l}\text { Harga Masker } \\
\text { Garnier sebanding } \\
\text { dengan manfaat } \\
\text { yang dijanjikan. }\end{array}$ & 33 & 47 & 19 & 1 & 0 \\
\hline 2 & $\begin{array}{l}\text { Harganya Masker } \\
\text { Garnier yang cukup } \\
\text { terjangkau. }\end{array}$ & 31 & 37 & 16 & 15 & 1 \\
\hline 3 & $\begin{array}{l}\text { Harga yang } \\
\text { ditawarkan Masker }\end{array}$ & 34 & 31 & 18 & 15 & 2 \\
\hline $\begin{array}{l}\text { Garnier sesuai } \\
\text { dengan kualitasnya. }\end{array}$ & & & & & \\
\hline
\end{tabular}


Berdasarkan tabel Tabel 4 diatas untuk indikator Harga yang sesuai dengan manfaat yakni:

a) 33 responden menyatakan sangant setuju

b) 47 responden setuju

c) 19 reponden netral

d) 1 reponden menyatakan tidak setuju

Jadi dapan disimpulkan bahawa dalam perbandingan masker garnier dan produk yang lain secara manfaat yang dijanjikan dalam promosi sesuai dengan kwalitasnya.

Sementara itu untuk respon harga terjangkau yakni:

a) 31 reponden menyatakan sangat setuju

b) 37 responden menyatakan setuju

c) 16 responden netral

d) 1 reponden tidak setuju

Dari hasil tersebut dapat dismpulkan bahwa respon konsumen terhadap harga garneir terjangkau lebih besar.

Untuk indicator kesesuaian harga dengan kualitas yakni:
a) 34 reponden sangat setuju
b) 31 reponden setuju
c) 18 menyatakan netral
d) 15 menyatakan tidak setuju
e) 2 responden menyakatakn sangat tidak setuju

Jadi dapat disimpulkan bahwa sebagian besar responden menyatakan sangat setuju dengan harga yang ditawarkan oleh masker garnier sebab sesuai dengan kualitasnya.

\section{c. Deskripsi Variabel Responden Keputusan Pembelian}

Pengukuran variabel keputusan pembelian dalam penelitian ini tersebar pada 3 butir pernyataan yang dibentuk dalam 3 definisi yang diadopsi dari Setiadi (2010) meliputi: (1) Kecepatan memutuskan membeli. (2) Yakin untuk membeli dan (3) Sesuai dengan kebutuhan.

Tabel 5. Tabel Tanggapan Responden Mengenai Keputusan Pembelian

\begin{tabular}{lllllll}
\hline \multirow{2}{*}{ No } & TANGGAPAN & \multicolumn{5}{c}{ SKOR } \\
\cline { 2 - 7 } & ST & S & N & TS & STS \\
\hline 1 & $\begin{array}{l}\text { Memutuskan } \\
\text { membeli Masker } \\
\text { Garnier saat } \\
\text { membutuhkan } \\
\text { produk Masker. }\end{array}$ & 43 & 28 & 17 & 14 & 0 \\
\hline 2 & $\begin{array}{l}\text { Saya yakin dalam } \\
\text { membeli Masker } \\
\text { Garnier. }\end{array}$ & 31 & 43 & 18 & 7 & 1 \\
\hline 3 & $\begin{array}{l}\text { Masker Garnier } \\
\text { sesuai dengan } \\
\text { kebutuhan saya. }\end{array}$ & 32 & 35 & 17 & 16 & 0 \\
\hline
\end{tabular}

Berdasarkan tabel Tabel 4.6 diatas untuk indikator ketertarikan iklan dari merek lain yakni:

a) 43 responden sangat setuju

b) 28 responden setuju

c) 17 responden setuju

d) 14 reponden tidak setuju

Jadi disimpulkan bahwa sebagian reponden sangat setuju dengan masker garnier dan memeutuskan untuk membelinya.

Untuk indicator yakin untuk memebeli masker garnier respon pembeli yakni:

a) 31 reponden sangat setuju

b) 43 responden setuju

c) 18 reponden netral

d) 7 reponden tidak setuju

e) 1 reponden sangat tidak setuju

Jadi dapat disimpulkan bahwa sebagaian besar reponden menyatakan yakin dan setuju untuk memebeli masker garnier.

Kemudian untuk respon yang dilakukan terhadap Reponden dalam memebeli masker garnier sesuai dengan kebutuhan yakni;
a) 32 Responden sangat setuju
b) 35 reponden setuju
c) 17 responden netral
d) 16 reponden tidak setuju 
Jadi dapat disimpulkan bahwa pendapat responden sebagaian besar mengatakan bahwa mereka setuju memebeli masker garnier karna sesuai dengan kebutuhan.

\subsection{Uji Instrumen Penelitian}

\section{a. Uji Validasi}

Dalam pengujian validasi peneliti menggunakan program SPSS dengan kriteria sebagai berikut;

1) Jika $r$ hitung positif atau $r>$ pada table maka butir pernyataan valid

2) Jika $r$ hitung negative atau $r$ hitung < table, maka butir pernyataan tersebut tidak valid.

Sementara itu peneyebaran kuisioner yang diuji validasinya diberikan kepada 100 orang reponden pemakai garnier. Nilai yang ada pada tebel $r$ dengan ketentuan $\mathrm{df}=\mathrm{n}-2$ aratinya $100-2=$ 98 dan tingkat signifikasi berjumlah 5\% dengan angka yang diperoleh 0,195.

Tabel 6. Hasil Uji Validitas

\begin{tabular}{|c|c|c|}
\hline No Indikator & \multicolumn{2}{|c|}{ r Hitung r Tabel KET. } \\
\hline \multicolumn{3}{|c|}{1 Variasi Produk } \\
\hline - Indikator 1 & 0,463 & 0,195 Valid \\
\hline - Indikator 2 & 0,745 & 0,195 Valid \\
\hline - Indikator 3 & 0,712 & 0,195 Valid \\
\hline \multicolumn{3}{|l|}{2 Harga } \\
\hline - Indikator 1 & 57 & 0,195 Valid \\
\hline - Indikator 2 & 64 & 0,195 Valid \\
\hline - Indikator 3 & 64 & 0,195 Valid \\
\hline \multicolumn{3}{|l|}{3 Iklan } \\
\hline - Indikator 1 & 51 & 0,195 Valid \\
\hline - Indikator 2 & 52 & 0,195 Valid \\
\hline - Indikator 3 & 64 & 0,195 Valid \\
\hline \multicolumn{3}{|c|}{4 Keputusan Pembelian } \\
\hline - Indikator 1 & 74 & 0,195 Valid \\
\hline - Indikator 2 & 69 & 0,195 Valid \\
\hline - Indikator 3 & 55 & 0,195 Valid \\
\hline
\end{tabular}

Melalui tebel di atas tergambar bahwa sbesar 12 pertanyaan yang diberikan kepada 100 responden maka reponden tersebut memeilki $\mathrm{r}$ table 0, 195 yang artinya semua pertanyaan valid.

\section{b. Uji Realibilitas}

Dalam pengujia Realibilitas peneliti menggunakan program SPSS yakni suatu variabel akan dinyatakan reliabel apabila nilai Croncach Alpha >0,06.

Tabel 7. Hasil uji Realibilitas

\begin{tabular}{ccc}
\hline VARIABEL & ALPHA & KET. \\
\hline $\begin{array}{c}\text { Variasi } \\
\text { Produk (X1) }\end{array}$ & 0,607 & reliabel \\
\hline Harga (X2) & 0,763 & reliabel \\
\hline Iklan (X3) & 0,743 & reliabel \\
\hline $\begin{array}{c}\text { Keputusan } \\
\text { Pembelian (y) }\end{array}$ & 0,626 & reliabel \\
\hline
\end{tabular}

Melalui table di atas maka dapat dilihat bahwa keseluruhan hasil uji reabilitas mnenunjukkan bahwa variasi produk, iklan, harga dan keutusan pemeblian memeiliki Cronbach Alpha lebih besar dari 0,06. Dengan demikian maka data kuisioner dalam penelitian ini sudah valid.

\subsection{Uji Asumsi Kalsik}

\section{a. Uji Normalitas}

Pengujian normalitas dapat dilakukan peneliti terhadap residun regresi. Dalam pegujian ini menggunakangrafik p-p Plot. Data yang dikategorikan normal adalah ketika data membentuk titik-titik yang tersebar tidak jauh dari garis diagonal.

Hal ini terlihat pada gambar di bawah ini.

Gambar 1. Gambar di bawah merupakan gambar histogram dan normal P-P Plot.

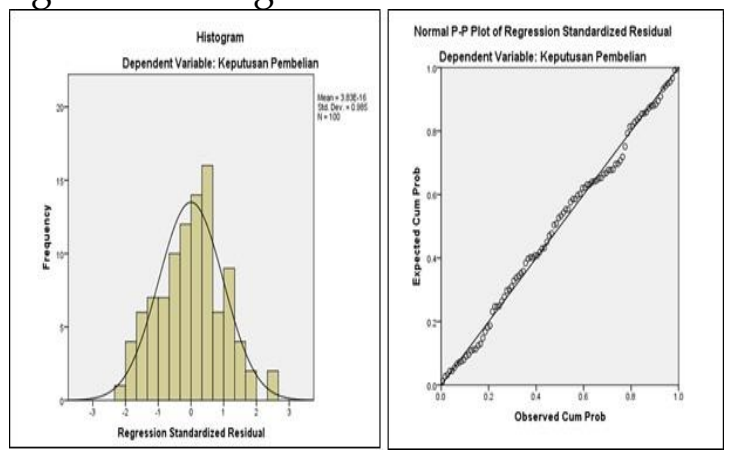

Pada gambar Histogram di atas kiri menenjukkan bahwa distribusi data yang benbentuk lonceng tidak keluar dari garis 
oleh sebab itu data dapat dikatakan sebagai pendistribusi normal. Sedangkan pada gambar atas kanan regresi yang diperoleh menunjukkan danya sebaran titik-titik yang tidak jauh dari garis horizontal.

\section{b. Uji Heterokedisitas}

Pada pengujian heterokeditas peneliti memakai Scatterplot. Pengujian ini bertujuan untuk mendapatkan variabel yang signifikan tentang produk sehingga tidak adanya masalah heterokedisitas. Dari hasil pengujian maka ditemukan tidak adanya masalah hal ini dapat dilihat pada gambar dibawah ini;

Gambar 2. Hasil Uji Heterokedisitas

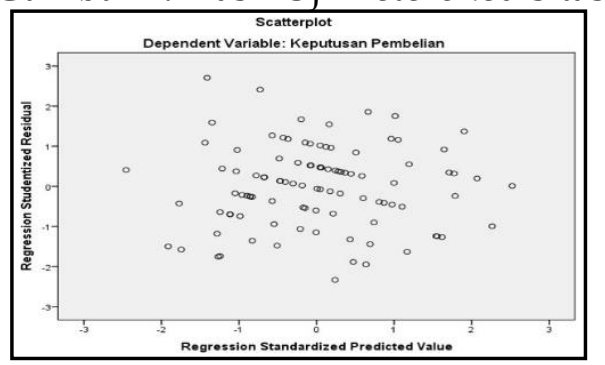

Hasil pengujian pada gambar di atas mengenai pengujian heterokedisitas menggambarkan bahwa tidak adanya pola yang jelas dari titik-titik tersebut. Sehingga dapat disimpulkan bahwa tidak adanya gejala heterokedisitas atau tidak adanya gangguan yang berarti dalam model regresi 0, 0307.

\section{KESIMPULAN}

Dari hasil pemabahasan di atas dapat disimpulkan bahwa adanya pengaruh yang signifikan terhadap penentuan harga terhadap keputusan pembelian garnier di Kabupaten Buru. Hal ini sesuai dengan pengujian variabel diantaranya yakni variabel variasi yakni sebesar 0,307 jadi ada pengaruh positif terhadap pembelian jika produk tersebut bervariasi dan pengujian variabel harga terhadap pengaruh pembelian dalam pengukuran variabel harga ditemukan adanya pengaruh positif terhadap keputusan pemmbelian yaitu 0,176.

\section{DAFTAR PUSTAKA}

Augusty, F. (2006). Metode Penelitian Manajemen: Pedoman Penelitian untuk skripsi, Tesis dan Disertai Ilmu Manajemen. Semarang: Universitas Diponegoro.

Buchari, A. (2005). Manajemen Pemesaran dan Pemasaran Jasa. cetakan 5. bandung: CV Alfabeta.

Djunaidi, F. G., Azwan, A. Y. T., Iye, R., \& bin Tahir, S. Z. Decks Range Gola Village Community Begun District Buton District North.

Groover, M.P. (2010). Fundamental of Modern Manufacturing Material, Processes and System, 4th edition, John Wiley and Sons, Hoboken, USA, p.456.

Iye, R. (2018). Tuturan emosi mahasiswa kota baubau dalam ranah demonstrasi [emotional speech of the students in baubau city in the demonstration]. TOTOBUANG, 6 (1), 125, 138.

Kotler, P. (2009). Manajemen Pemasaran: Analisis, Perencanaan, Implementasi, dan Kontrol. Jilid 1. Edisi Bahasa Indonesia dari Principles of Marketing Ge.Jakarta: Penerbit PT. Prenhalindo

Singarimbun, M \& Sofian, E. (1989). Metode Penelitian Survey. Jakarta: LP3ES.

Sujarweni, V. Wiratna. (2015). Akuntansi Manajemen. Yogyakarta: Pustaka Baru Press.

Sugiono. (2010). Metode Penelitian Bisnis. Bandung: alfabeta.

Tjiptono, F. (2010). Strategi Pemasaran, Edisi 2. Yogyakarta: Andi Offset. 